\title{
Lipotoxicity and the role of maternal nutrition
}

Citation for published version (APA):

Pruis, M. G., van Ewijk, P. A., Schrauwen-Hinderling, V. B., \& Plosch, T. (2014). Lipotoxicity and the role of maternal nutrition. Acta Physiologica, 210(2), 296-306. https://doi.org/10.1111/apha.12171

Document status and date:

Published: 01/02/2014

DOI:

10.1111/apha.12171

Document Version:

Publisher's PDF, also known as Version of record

Document license:

Taverne

Please check the document version of this publication:

- A submitted manuscript is the version of the article upon submission and before peer-review. There can be important differences between the submitted version and the official published version of record.

People interested in the research are advised to contact the author for the final version of the publication, or visit the DOI to the publisher's website.

- The final author version and the galley proof are versions of the publication after peer review.

- The final published version features the final layout of the paper including the volume, issue and page numbers.

Link to publication

\footnotetext{
General rights rights.

- You may freely distribute the URL identifying the publication in the public portal. please follow below link for the End User Agreement:

www.umlib.nl/taverne-license

Take down policy

If you believe that this document breaches copyright please contact us at:

repository@maastrichtuniversity.nl

providing details and we will investigate your claim.
}

Copyright and moral rights for the publications made accessible in the public portal are retained by the authors and/or other copyright owners and it is a condition of accessing publications that users recognise and abide by the legal requirements associated with these

- Users may download and print one copy of any publication from the public portal for the purpose of private study or research.

- You may not further distribute the material or use it for any profit-making activity or commercial gain

If the publication is distributed under the terms of Article $25 \mathrm{fa}$ of the Dutch Copyright Act, indicated by the "Taverne" license above, 


\title{
REVIEW
}

\section{Lipotoxicity and the role of maternal nutrition}

\author{
M. G. M. Pruis,' P. A. van Ewijk, ${ }^{2,3}$ V. B. Schrauwen-Hinderling ${ }^{2}$ and T. Plösch' \\ I Department of Pediatrics, Laboratory Medicine, Center for Liver, Digestive and Metabolic Diseases, University Medical Center \\ Groningen, University of Groningen, Groningen, the Netherlands \\ 2 Department of Radiology, Maastricht University Medical Center, Maastricht, the Netherlands \\ 3 Department of Human Biology, Maastricht University Medical Center, Maastricht, the Netherlands
}

Received 17 July 2013, revision requested 12 August 2013 ,

revision received 23 August 2013, accepted 20 September 2013 Correspondence: T. Plösch,

Department of Obstetrics and Gynaecology, University Medical Center Groningen, PO Box 30.00I, 9700 RB Groningen, The Netherlands. E-mail: t.plosch@umcg.nl URL: www.epigenetic-pro gramming.n!

\begin{abstract}
Intrauterine malnutrition predisposes the offspring towards the development of type 2 diabetes and cardiovascular disease. To explain this association, the Developmental Origins of Health and Disease hypothesis was introduced, meaning that subtle environmental changes during embryonic and foetal development can influence post-natal physiological functions. Different mechanisms, including epigenetics, are thought to be involved in this foetal programming, but the link between epigenetics and disease is missing. There is increasing evidence that ectopic lipid accumulation and/ or lipotoxicity is induced by foetal programming. The aim of this review is to provide insights into the mechanisms underlying lipotoxicity through programming, which contributes to the increase in hepatic and cardiac metabolic risk.

Keywords foetal programming, heart failure, lipotoxicity, non-alcoholic steatohepatitis, obesity.
\end{abstract}

The prevalence of obesity and the metabolic syndrome is rapidly increasing, paving the way for the development of diabetes and cardiovascular disease. In the etiology of these diseases, fat storage in non-adipose tissue, at so-called ectopic sites, is an important factor (Cusi 2012). Elevated hepatic fat content is strongly linked with insulin resistance, dyslipidemia and all other facets of the metabolic syndrome. Excessive cardiac lipid content is associated with the development of cardiomyopathy and cardiac dysfunction (McGavock et al. 2006).

In spite of all the efforts to promote weight loss and a healthier lifestyle, the prevalence of the metabolic syndrome is still rising. A yet-underestimated factor in the etiology of the metabolic syndrome and related diseases may be the early developmental environment that is known to exert long-lasting influences by so-called 'metabolic programming'. This programming of the foetus to developmental conditions was also called 'developmental programming' (Lucas 1998, McMillen \& Robinson 2005) or 'developmental plasticity' (Barker 2004), and leads to permanent changes in tissue structure and function. A large number of epidemiological studies have shown the association between impaired foetal nutrition and development of obesity, hypertension, diabetes and cardiovascular disease (Barker \& Osmond 1986, Ravelli et al. 1998, Nohr et al. 2008, Fraser et al. 2010, Laitinen et al. 2012). Studies in animal models indicate that maternal overnutrition has similar effects.

While the relationship between early developmental events and adult disease has become evident, the biological mechanisms behind these programming effects have remained largely unclear, although epigenetic modifications and differences in cell type composition may be involved (Barnes \& Ozanne 2011, Jimenez-Chillaron et al. 2012). The importance of foetal and early postnatal life is currently extensively studied to clarify the physiological and molecular links between events during this developmental period and long-term health. Evidence is accumulating that the ectopic deposition of 
fat may be mechanistically involved in the long-term programming of disease, thus linking epigenetic effects and physiological outcome.

This review highlights the relation between maternal nutrition and hepatic and cardiac lipid metabolism in adult offspring.

\section{Complexity of nutritional programming}

The investigation of the relationship between maternal diet and lipid metabolism in offspring is complex, as it is influenced by many factors. As the foetus develops at different rates during development, the timing of the insult is important in determining the specificity of programming. Several animal studies have shown the different effects of under- or overnutrition during different stages of pregnancy on programming of the foetus. For example, in a rat study in which dams were exposed to low-protein diets at different time-windows during pregnancy, timing was shown to have differential effects on offspring (Langley-Evans et al. 1996). Similarly, the timing of nutrient restriction in sheep was shown to be important for the phenotype of the offspring (Gilbert et al. 2005). This exposure effect is also well-documented in humans. During the Dutch Hunger Winter, the effects of maternal nutrient restriction on the offspring during late- and mid-gestation were especially pronounced (Ravelli et al. 1998, Roseboom et al. 1999).

In addition to exposure timing, nutritional conditions after weaning have been shown to be important for the health effects measured. In sheep exposed to pre- and/or post-natal undernutrition, it was found that a mismatch between pre- and post-natal nutrition leads to unfavourable outcomes (Cleal et al. 2007). Interestingly, pre- and post-natal exposure to a highfat diet did not prevent development of raised blood pressure in a rat model (Khan et al. 2004). In fact, evidence accumulates that pre-natal exposure to a high-fat diet renders offspring especially sensitive to 'lipotoxic' effects of post-natal high-fat diets (Bruce et al. 2009).

Several studies demonstrated sex-specific effects of developmental exposure to under- or overnutrition (Khan et al. 2003, McMullen \& Langley-Evans 2005, Samuelsson et al. 2013). However, an extensive review on sexual dimorphism and epigenetic programming can be found elsewhere (Gabory et al. 2009).

Programming effects are dependent on specific nutrient deficiency or surplus. At present, an increasing number of animal studies are performed using high-fat diets. Maternal exposure to a high-fat diet rich in saturated fatty acids had detrimental effects in offspring (Khan et al. 2003, 2005), while maternal exposure to polyunsaturated fatty acids showed beneficial effects in female rat offspring (Chechi \&
Cheema 2006). Ultimately, future research needs to determine which specific signals provoke the programming effects in the target tissues of the foetus. Paradoxically, a general surplus of fatty acids in a high-fat diet may out-compete transport of a single key fatty acid in the placenta, leading to a deficit in the presence of plenty.

\section{The role of foetal programming in the development of non-alcoholic fatty liver disease in epidemiological studies}

Several epidemiological studies implicate an intrauterine contribution to adult liver disease. Although there is little literature about the specific effects of maternal nutrition on birth size in humans, there are many papers highlighting these effects under extreme conditions, like severe starvation (exemplified by the Dutch Hunger Winter, see Ravelli et al. 1999). It should be noted, however, that intrauterine growth restriction may have a plethora of other (often unknown) causes. Human infants born small-for-gestational-age were found to have reduced liver dimensions, as measured by ultrasonography at birth (Latini et al. 2004). In addition, low birth size in men, but not women, is associated with increased total cholesterol in blood, which is at least partially regulated by the liver (Davies et al. 2004). A large Danish prospective record linkage study showed the strongest correlation between measures of birth size and cause-specific mortality for deaths attributed to liver cirrhosis (Andersen \& Osler 2004). Fraser et al. examined the association of birthweight with adult markers of liver damage and function in a random sample of 2101 British women. They found a small but consistent inverse linear association between birthweight and adult age-adjusted levels of alanine aminotransferase (ALT) and gamma glutamyltransferase (GGT; Fraser et al. 2008). ALT and GGT are liver-specific markers and are considered biomarkers of non-alcoholic fatty liver disease (NAFLD). The inverse association of birthweight with ALT and GGT supports the hypothesis that intrauterine exposure may contribute to the onset of NAFLD.

\section{Evidence of foetal programming in the development of NAFLD from animal models}

There are large numbers of well-established animal models that have indicated a link between foetal growth and NAFLD. The first evidence for programming of NAFLD comes from models using nutritionally restricted diets, although the greatest impact is seen in overnourished models. Mouse models of maternal overweight or overnutrition have shown convincing evidence of foetal programming of NAFLD 
in offspring (Zhang et al. 2005, Bruce et al. 2009, Elahi et al. 2009, Gregorio et al. 2010, Ashino et al. 2012).

\section{Hepatic hypertrophy}

Structural changes have been noted in the liver of offspring from malnourished mothers. Hepatic lobules of protein-restricted rat offspring were described as having double the mean volume of lobules from control livers, without changes in relative liver weight (Burns et al. 1997). Moreover, several mouse models of maternal malnutrition show hepatic hypertrophy in the offspring (Samuelsson et al. 2008, Shankar et al. 2010). While not every studies reports hepatic hypertrophy, increases in liver derived enzymes (ALT and AST) are sometimes observed (Gregorio et al. 2010, Oben et al. 2010, Hyatt et al. 2011), a change that often accompanies hepatic hypertrophy and may appear in plasma after liver enlargement. Taken together, these results indicate that hepatic hypertrophy is a frequently noted phenomenon accompanying gestational malnutrition.

Hepatic hypertrophy can be induced by several factors including altered oxidative status, fatty acid metabolism, energy production and utilization, cell turnover and altered hepatocellular cytoplasmic, and nuclear morphology (Hall et al. 2012). Several of these factors have been reported in foetal programming of offspring health (Burns et al. 1997, Bruce et al. 2009).

\section{Liver function}

In addition to structural changes, there have been numerous reports that liver functionality is affected by maternal malnutrition. In rats partially deprived of protein during pregnancy, gluconeogenesis and hepatic glucose handling in offspring are altered compared to controls (Burns et al. 1997). Glucose output from lactate is increased in maternal low-protein offspring, which is related to the difference in glucose handling. One possible mechanism is increased glucogenesis because of the greater absolute phosphoenolpyruvate carboxykinase (PEPCK) activity found in these livers (Burns et al. 1997). Additionally, several animal models of maternal overnutrition indicate mitochondrial abnormalities in the liver of offspring (Bruce et al. 2009, Burgueno et al. 2013). Bruce et al. (2009) reported that the activity of the hepatic mitochondrial electron transport chain enzyme complex (I, II/III and IV) is reduced in offspring of high-fat-fed mothers. In the progression from NAFLD to non-alcoholic steatohepatitis, inflammatory pathways, which are also affected by foetal programming, are important. In that context, it has recently been reported that offspring from overnourished dams showed increased Kupffer cell numbers with impaired phagocytic function and raised reduced oxygen species synthesis together with reduced natural killer $\mathrm{T}$ cells and raised interleukin 12 and interleukin 18 levels (Mouralidarane et al. 2013). Even though many of these animal models use different diets and different strategies, all accumulate fat in the liver and liver functionality seems to be altered in one way or the other (Table 1).

\section{Lipotoxicity}

Excessive hepatic fat storage has been shown in many animal models of foetal programming. While hepatic fat accumulation is not necessarily malignant, it is often associated with insulin resistance (Savage \& Semple 2010). Models of maternal restriction, overnutrition and glucocorticoid exposure show increased body fat and altered hepatic lipid metabolism in offspring, accompanied by accumulating triglycerides and cholesterol, characteristics of hepatic steatosis (Bruce et al. 2009, Elahi et al. 2009, Drake et al. 2011, Ashino et al. 2012).

It is still unclear what is underlying the increased lipid accumulation. Impaired oxidative capacity (impaired mitochondrial function) may be of importance; on the other hand, several animal models report a lipogenic transcriptome signature early in the development of the liver (McCurdy et al. 2009, Shankar et al. 2010). Non-human primates of overnourished mothers show signs of NAFLD beginning in the early third trimester, including hepatic inflammation, oxidative stress, triglyceride accumulation and gluconeogenic gene activation (McCurdy et al. 2009). This is associated with PPAR gamma coactivator 1 alpha (PGC1a) deacetylation and increased hepatocyte nuclear factor 4 alpha (HNF4a) expression in the foetal liver, suggesting an important early mechanism by which excess lipids may reprogram hepatic lipid and glucose metabolism in the liver. In this study, the elevation of hepatic triglyceride levels persisted until adolescence with a twofold increase in per cent body fat. Another study performed in rats found increased per cent liver weight, enlarged hepatocytes and lipid accumulation in livers of offspring at weaning; it is suggested that exposure to maternal overweight programs systemic changes in insulin and adiponectin levels and alteration of genes involved in carbohydrate metabolism, lipid biosynthesis and fatty acid catabolism. Interestingly, sterol regulatory element-binding protein 1 (SREBP1) was increased and identified as a common regulator of the altered genes, in addition, a decrease in PPAR-a-AMPK signalling was indicated (Shankar et al. 2010).

In contrast, Krasnow et al. (2011) found no differences in triglyceride accumulation and hepatic inflammation in 


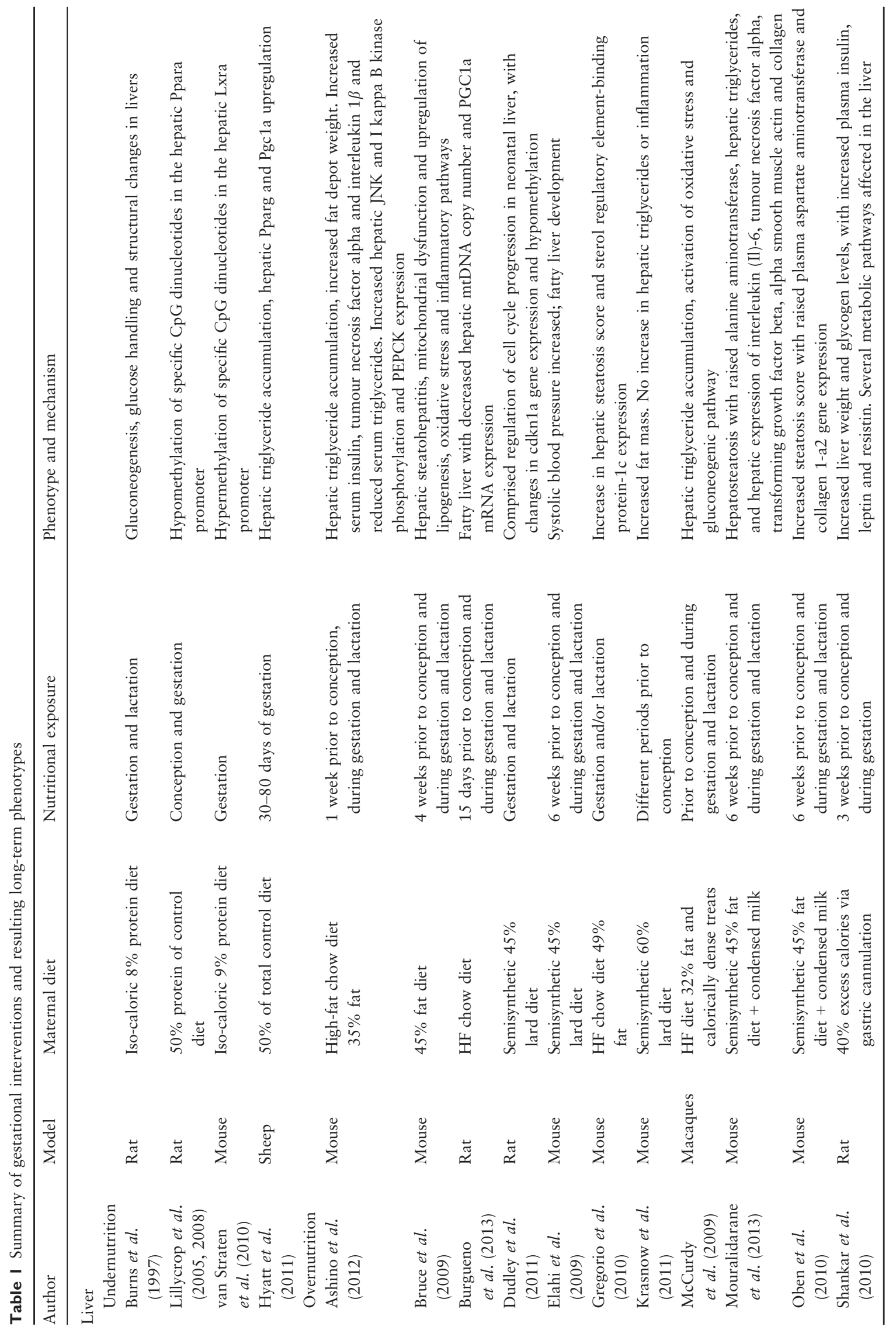



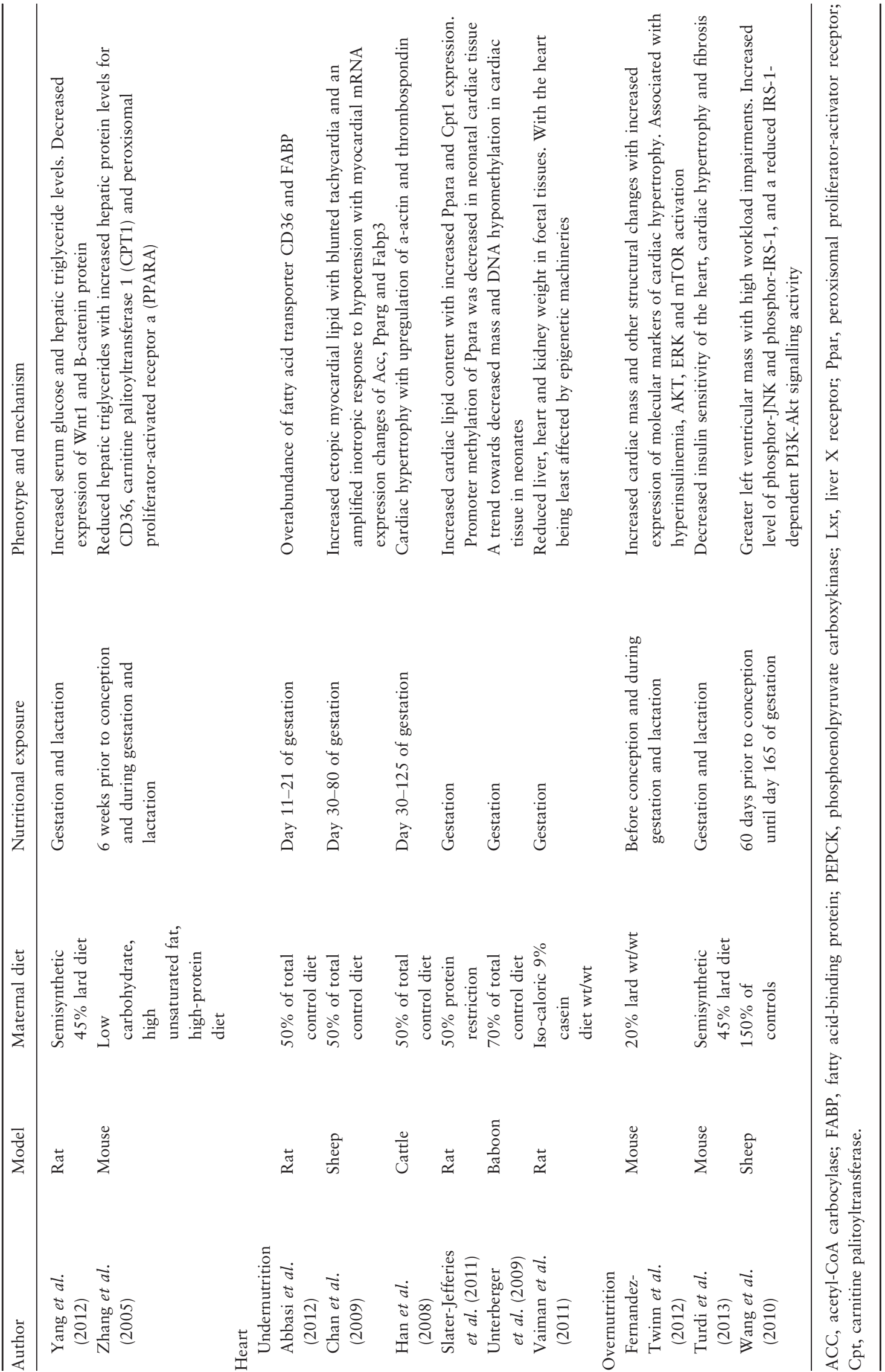

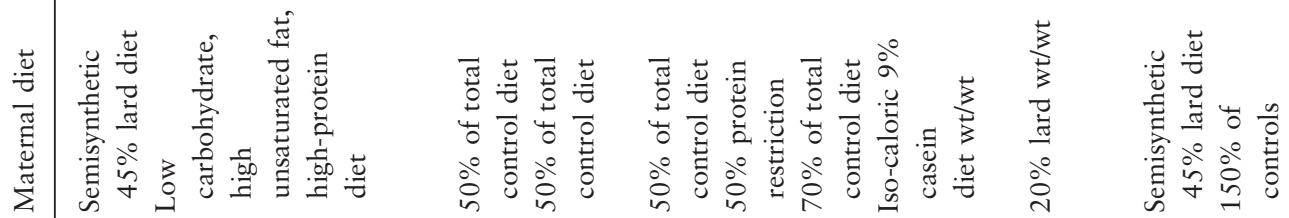
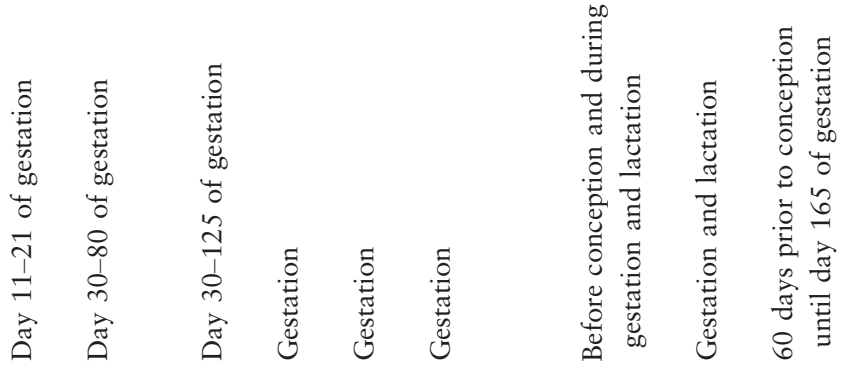

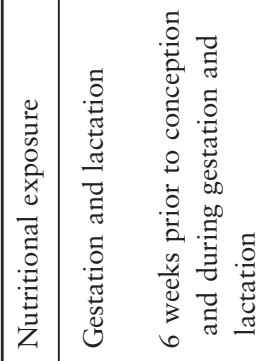
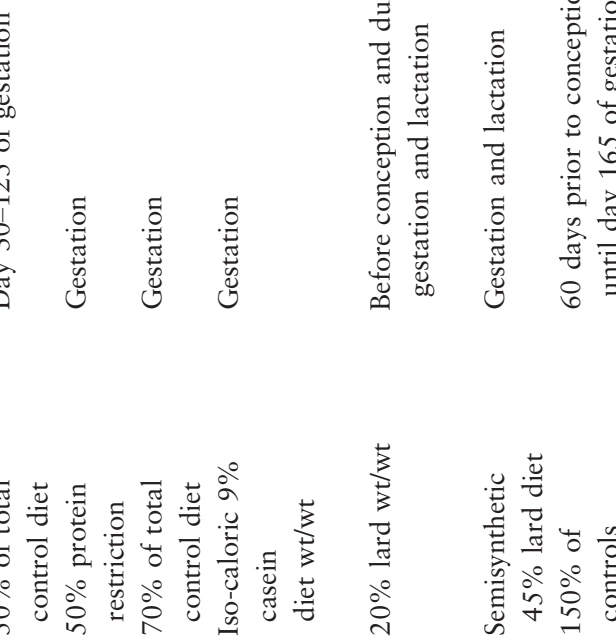

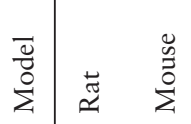

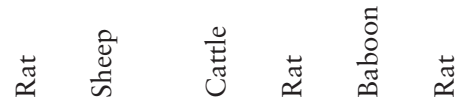

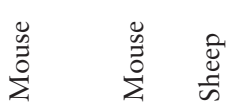
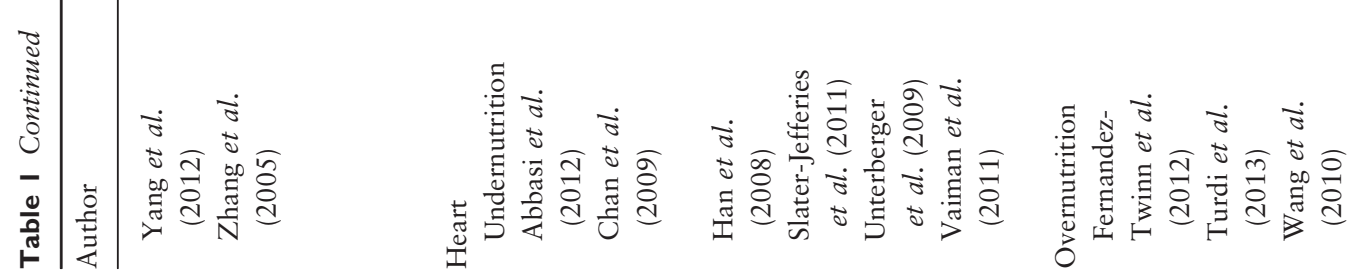
newborn mice. However, they reported an increase in fat mass in offspring from mothers fed a high-fat diet.

Currently, most of the research points towards programming of multiple aspects of energy-balance regulation in the offspring during gestational exposure to malnutrition. Therefore, an early change in a lipogenic pathway could be a cause in the development of NAFLD, because the transcriptome is already altered very early in life.

\section{Epigenetics}

During the past decade, the role of epigenetics in the pathogenesis of disease has been increasingly recognized. However, the specific role of epigenetics in the pathogenesis of NAFLD is largely unknown. A recent study in human patients showed a tight interaction between the presence of NAFLD and hepatic DNA methylation of PGC1A and mitochondrial transcription factor A promoters (Sookoian et al. 2010).

In rodents, numerous studies focus on the consequences of maternal nutrition on the liver epigenome. Promoters of nuclear receptors are relatively well-studied candidates for differential methylation. Lillycrop et al. $(2005,2008)$ characterized changes in methylation and expression of the glucocorticoid receptor and peroxisome proliferator-activated receptor (Ppar) alpha. van Straten et al. (2010) made similar observations for the liver $\mathrm{X}$ receptor alpha (LXRa), among 200 other loci. It seems plausible that changes in these key factors have long-term consequences for the regulation of metabolism, especially under challenging nutritional conditions.

On the other nutritional extreme, two recent reports showed that maternal high-fat diet may alter DNA methylation and gene expression in the offspring. First, maternal high-fat feeding reduces methylation and increased expression of the cyclin-dependent kinase inhibitor 1A (Cdkn1a) during neonatal liver development (Dudley et al. 2011). This alteration is responsible for changing hepatic proliferation and liver size, two aspects that are compatible with the development of a fatty liver phenotype (Bruce et al. 2009). The second report demonstrated that in offspring with increased serum glucose and liver triglyceride levels, hepatic Wnt1 (wingless-type MMTV integration site family, member 1) activity is affected through histone modifications (Yang et al. 2012).

\section{Epidemiological evidence of foetal programming in the development of cardiovascular disease}

Barker and colleagues were the first to describe an association between maternal health status and mor- tality of offspring from cardiovascular disease and stroke. The relationship became apparent when investigating regional differences in mortality owing to stroke and cardiovascular disease in England and Wales (Barker \& Osmond 1986, Barker et al. 1989). Currently, adverse effects of foetal programming on cardiovascular health are well-documented (McMillen \& Robinson 2005).

Many studies report an increased prevalence of hypertension with low birthweight and report inverse correlations between birthweight and blood pressure (Huxley et al. 2000, 2002). The underlying mechanism of the relation between birthweight and blood pressure is not fully understood. Several mechanisms have been proposed, including reduced nephron number in low birthweight, possibly resulting in hyperfiltration and damage of the remaining nephrons, which favours the development of hypertension. Furthermore, vascular and endothelial dysfunction is associated with low birthweight, contributing to high blood pressure and microvascular structural changes observed in animal models of intrauterine growth restriction. Also, changes in the sympathetic nervous system may be involved in the increased risk to develop hypertension. Additionally, various studies report endocrine changes with high levels of aldosterone and cortisol in low birthweight, which can also influence blood pressure (Edvardsson et al. 2012).

Other systemic risk factors for cardiovascular disease besides blood pressure can be affected: it has been shown that oversupply of substrate during early development leads to changes in plasma metabolites. In that respect, increased plasma high-density lipoprotein cholesterol (HDL-C), triglycerides, apolipoprotein A1 (apoA1) and interleukin 6 (IL-6) concentrations were found in offspring of mothers with large gestational weight gain (Fraser et al. 2010).

\section{The heart as target of foetal programming}

Foetal programming not only influences systemic risk factors for cardiovascular disease but also affects the cardiac muscle directly. This can cause hypertrophy, hamper cardiac function and may modulate cardiac metabolism, lipid oxidation and lipid storage (Table 1).

\section{Hypertrophy}

Several animal studies show that both nutrient restriction and oversupply during pre-natal development lead to cardiac hypertrophy in offspring. Cardiac gene expression in the offspring of nutritionally restricted steers showed upregulation of genes that are typically associated with maladaptive cardiac hypertrophy (Han et al. 2008). On the other hand, maternal obesity may also lead to hypertrophy in offspring, as investigated 
in mice. Cardiac geometry and gene expression was shown to be affected in offspring of obese mice. These changes are suggested to be owing to the activation of the protein kinase $\mathrm{B}$, the extracellular signal-regulated kinase and mammalian target of rapamycin pathway (AKT-ERK-mTOR pathway; Fernandez-Twinn et al. 2012).

A human study confirms the importance of maternal obesity in developing hypertrophy. The heart weight of 6-month-old infants was investigated by ultrasound and the offspring of the women who gained the greatest weight during pregnancy were characterized by heavier hearts than offspring from women with appropriate weight gain (Geelhoed et al. 2008).

\section{Cardiac function}

The environment during the early developmental phase seems to have lasting impact on contractile function of the heart with nutritional restriction (Chan et al. 2009) and oversupply impairing cardiac function in offspring, as shown in a study with an obese sheep model (Wang et al. 2010). Cardiac function in offspring may be normal at baseline, but impairments may become apparent at high workloads only, as shown in offspring of obese sheep (Wang et al. 2010). It was shown that plasma levels of tumour necrosis factor alpha (TNF alpha) and leptin are elevated in offspring when ewes were obese and it was suggested that these changes may underlie the negative ionotropic effect on the heart of the offspring (Oral et al. 1997, Vickers 2007).

\section{Lipotoxicity}

Excessive fat storage in the heart is related to cardiac pathology in obesity and diabetes, and is manifested in increased cardiac myocyte apoptosis, myocardial fibrosis, left ventricular chamber expansion, contractile dysfunction and impaired diastolic filling (McGavock et al. 2006). The association between cardiac lipid content and cardiac dysfunction is termed 'cardiac lipotoxicity' and has been described in several genetic rodent models in mice and rats.

In animal models, it was clearly shown that maternal undernutrition or nutrient restriction influences lipid metabolism and increases cardiac fat storage in offspring. The offspring of nutrient-restricted sheep responded differently to an obesogenic diet than the offspring of non-restricted animals, showing a threefold higher increase in myocardial fat deposition. This was accompanied by altered myocardial mRNA expression of acetyl-CoA carbocylase, peroxisome proliferator-activated receptor gamma (PPARg) and fatty acid-binding protein (FABP) 3 in the animals that were exposed to nutrient restriction during early development (Chan et al. 2009). Protein restriction during pregnancy in rats was also shown to result in increased cardiac lipid content in the offspring, together with increases in gene expression of PPARa and carnitine palmitoyl transferase 1 (CPT1; SlaterJefferies et al. 2011).

The exact mechanism by which cardiac lipid content is increased in growth-restricted animal models is not identified. However, a study with intrauterine growth restriction in rats has shown overabundance of the fatty acid transporters CD36 and FABP in the hearts of growth-restricted animals, which may underlie or contribute to cardiac lipid accumulation (Abbasi et al. 2012).

As described above, cardiac lipid accumulation occurs in nutrient restriction/intrauteral growth retardation. However, results from animal models suggest that overconsumption of fat during pregnancy has similar effects on the offspring, increasing their susceptibility to the negative effects of a post-natal high-fat diet. Interaction of maternal high-fat diet with post-natal high-fat diet in mice was shown to decrease mitochondrial integrity in the heart and to increase cardiac lipid content. The offspring that were exposed to high-fat diet in utero also showed decreased insulin sensitivity of the heart, decreased cardiac function and was characterized by increased hypertrophy, apoptosis and fibrosis (Turdi et al. 2013).

\section{Epigenetics}

Very little is known about the epigenetic mechanisms involved in the changes that occur in the heart because of maternal over- or undernutrition. One of the few studies investigating this issue has been performed in baboons and found a trend towards DNA hypomethylation in cardiac tissue of the offspring that underwent nutrient restriction (Unterberger et al. 2009). A more recent study in mice has found that the offspring that had been subjected to protein restriction during gestation were characterized by decreased methylation of the promoter region of PPARa, resulting in changes in mRNA expression (Slater-Jefferies et al. 2011). However, when investigating epigenetic regulator genes in the offspring of protein-restricted rats, no significant changes could be detected in the heart (Vaiman et al. 2011). Clearly, more studies are needed to understand these mechanisms in detail. Future studies will have to address the epigenetic mechanisms that convey the cardiac effects of maternal high-fat feeding and overnutrition to the next generation. 
Figure I Lipotoxicity as a common pathway of organ dysfunction through fetal programming.

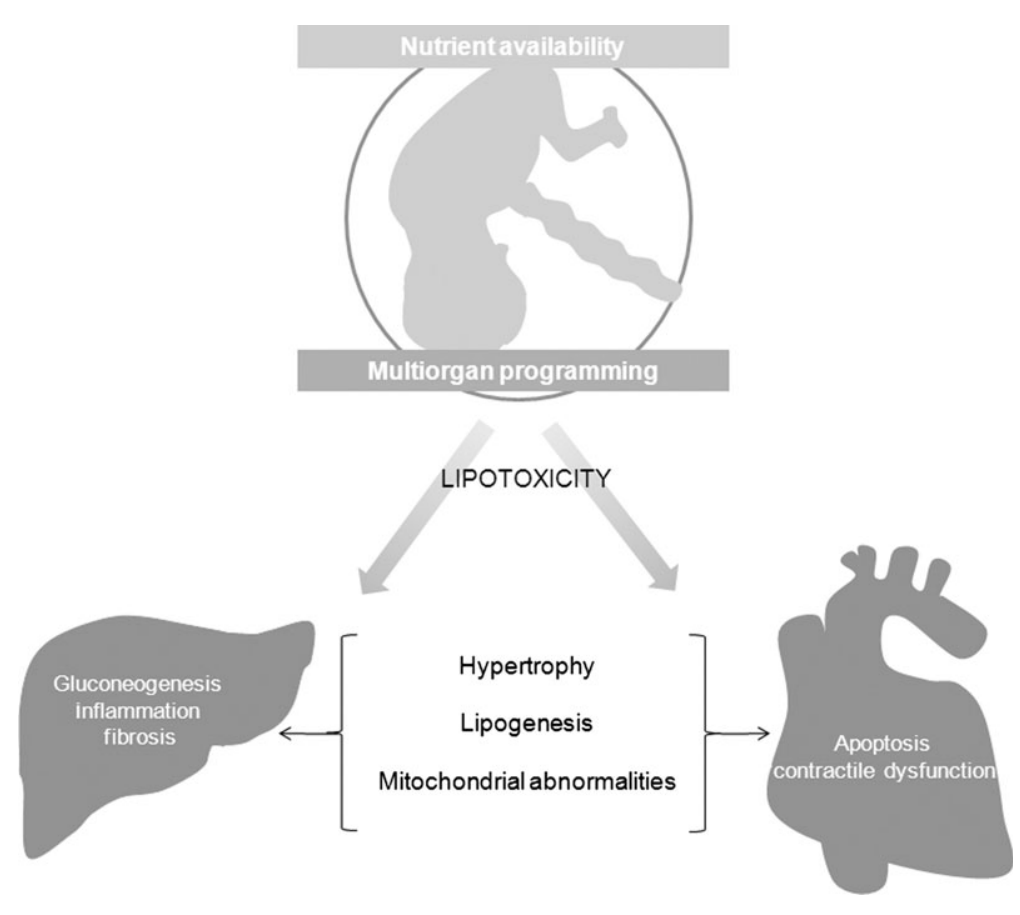

\section{Conclusion}

Taken together, there is convincing evidence that prenatal exposure to either dietary shortage or overabundance increases the susceptibility for ectopic lipid accumulation in heart and liver. Furthermore, other metabolic-risk factors also rise owing to a suboptimal environment during early development: blood pressure can increase, cardiac function deteriorates, and plasma lipids and inflammatory markers can increase (Fig. 1). Together, these factors contribute to the phenomenon now known as Developmental Origins of Health and Disease or Barker hypothesis. The molecular mechanisms responsible for the programming of offspring have yet to be fully elucidated. Similar pathways in different organs that lead to the development of metabolic disease owing to programming should be investigated further. So far, in animal studies, it was found that protein restriction during pregnancy alters DNA methylation of the PPARa promoter in heart and liver of the offspring (Lillycrop et al. 2008, Slater-Jefferies et al. 2011) among others. Growing evidence supports the concept that epigenetic mechanisms play a role in foetal programming (Heerwagen et al. 2010, JimenezChillaron et al. 2012), which may well be a common mechanism in the development of different organs. Future research will have to unravel the full impact of foetal programming on metabolic disease. The elucidation of underlying mechanisms will support the development of preventive strategies or the early identification of persons-at-risk.

\section{Conflict of interest}

The authors have no conflicts of interest to declare.

This research was performed within the framework of CTMM, the Center for Translational Molecular Medicine (www.ctmm.nl), project PREDICCt (grant 01C-104), and supported by the Dutch Heart Foundation, Dutch Diabetes Research Foundation and Dutch Kidney Foundation. Torsten Plösch is supported by the Dutch Heart Foundation (grant 2004T4801), the Netherlands Organization for Scientific Research (TOP ZonMw 40008129811053), and by the Dutch Technology Foundation STW (www.stw.nl), which is part of the Netherlands Organisation for Scientific Research (NWO) and is partly funded by the Ministry of Economic Affairs. Vera Schrauwen-Hinderling is supported by a VENI (grant 91611136) for innovative research from the Netherlands Organization for Scientific Research (NWO).

\section{References}

Abbasi, A., Thamotharan, M., Shin, B.C., Jordan, M.C., Roos, K.P., Stahl, A. \& Devaskar, S.U. 2012. Myocardial macronutrient transporter adaptations in the adult pregestational female intrauterine and postnatal growth-restricted offspring. Am J Physiol Endocrinol Metab 302, E1352-E1362.

Andersen, A.M. \& Osler, M. 2004. Birth dimensions, parental mortality, and mortality in early adult age: a cohort study of Danish men born in 1953. Int J Epidemiol 33, 92-99.

Ashino, N.G., Saito, K.N., Souza, F.D., Nakutz, F.S., Roman, E.A., Velloso, L.A., Torsoni, A.S. \& Torsoni, M.A. 2012. Maternal high-fat feeding through pregnancy and lactation 
predisposes mouse offspring to molecular insulin resistance and fatty liver. J Nutr Biochem 23, 341-348.

Barker, D.J. 2004. The developmental origins of chronic adult disease. Acta Paediatr Suppl 93, 26-33.

Barker, D.J. \& Osmond, C. 1986. Infant mortality, childhood nutrition, and ischaemic heart disease in England and Wales. Lancet 1, 1077-1081.

Barker, D.J., Osmond, C., Golding, J., Kuh, D. \& Wadsworth, M.E. 1989. Growth in utero, blood pressure in childhood and adult life, and mortality from cardiovascular disease. BMJ 298, 564-567.

Barnes, S.K. \& Ozanne, S.E. 2011. Pathways linking the early environment to long-term health and lifespan. Prog Biophys Mol Biol 106, 323-336.

Bruce, K.D., Cagampang, F.R., Argenton, M., Zhang, J., Ethirajan, P.L., Burdge, G.C., Bateman, A.C., Clough, G.F., Poston, L., Hanson, M.A., McConnell, J.M. \& Byrne, C.D. 2009. Maternal high-fat feeding primes steatohepatitis in adult mice offspring, involving mitochondrial dysfunction and altered lipogenesis gene expression. Hepatology 50, 1796-1808.

Burgueno, A.L., Cabrerizo, R., Gonzales Mansilla, N., Sookoian, S. \& Pirola, C.J. 2013. Maternal high-fat intake during pregnancy programs metabolic-syndrome-related phenotypes through liver mitochondrial DNA copy number and transcriptional activity of liver PPARGC1A. J Nutr Biochem 24, 6-13.

Burns, S.P., Desai, M., Cohen, R.D., Hales, C.N., Iles, R.A., Germain, J.P., Going, T.C. \& Bailey, R.A. 1997. Gluconeogenesis, glucose handling, and structural changes in livers of the adult offspring of rats partially deprived of protein during pregnancy and lactation. J Clin Invest 100, 1768-1774.

Chan, L.L., Sebert, S.P., Hyatt, M.A., Stephenson, T., Budge, H., Symonds, M.E. \& Gardner, D.S. 2009. Effect of maternal nutrient restriction from early to midgestation on cardiac function and metabolism after adolescent-onset obesity. Am J Physiol Regul Integr Comp Physiol 296, R1455-R1463.

Chechi, K. \& Cheema, S.K. 2006. Maternal diet rich in saturated fats has deleterious effects on plasma lipids of mice. Exp Clin Cardiol 11, 129-135.

Cleal, J.K., Poore, K.R., Boullin, J.P., Khan, O., Chau, R., Hambidge, O., Torrens, C., Newman, J.P., Poston, L., Noakes, D.E., Hanson, M.A. \& Green, L.R. 2007. Mismatched pre- and postnatal nutrition leads to cardiovascular dysfunction and altered renal function in adulthood. Proc Natl Acad Sci USA 104, 9529-9533.

Cusi, K. 2012. Role of obesity and lipotoxicity in the development of nonalcoholic steatohepatitis: pathophysiology and clinical implications. Gastroenterology 142, 711-725.

Davies, A.A., Smith, G.D., Ben-Shlomo, Y. \& Litchfield, P. 2004. Low birth weight is associated with higher adult total cholesterol concentration in men: findings from an occupational cohort of 25,843 employees. Circulation 110, 1258-1262.

Drake, A.J., Liu, L., Kerrigan, D., Meehan, R.R. \& Seckl, J.R. 2011. Multigenerational programming in the glucocorticoid programmed rat is associated with generation- specific and parent of origin effects. Epigenetics 6, 1334-1343.

Dudley, K.J., Sloboda, D.M., Connor, K.L., Beltrand, J. \& Vickers, M.H. 2011. Offspring of mothers fed a high fat diet display hepatic cell cycle inhibition and associated changes in gene expression and DNA methylation. PLoS ONE 6, e21662.

Edvardsson, V.O., Steinthorsdottir, S.D., Eliasdottir, S.B., Indridason, O.S. \& Palsson, R. 2012. Birth weight and childhood blood pressure. Curr Hypertens Rep 14, 596-602.

Elahi, M.M., Cagampang, F.R., Mukhtar, D., Anthony, F.W., Ohri, S.K. \& Hanson, M.A. 2009. Long-term maternal high-fat feeding from weaning through pregnancy and lactation predisposes offspring to hypertension, raised plasma lipids and fatty liver in mice. Br J Nutr 102, 514-519.

Fernandez-Twinn, D.S., Blackmore, H.L., Siggens, L., Giussani, D.A., Cross, C.M., Foo, R. \& Ozanne, S.E. 2012. The programming of cardiac hypertrophy in the offspring by maternal obesity is associated with hyperinsulinemia, AKT, ERK, and mTOR activation. Endocrinology 153, 5961-5971.

Fraser, A., Ebrahim, S., Smith, G.D. \& Lawlor, D.A. 2008. The associations between birthweight and adult markers of liver damage and function. Paediatr Perinat Epidemiol 22, $12-21$.

Fraser, A., Tilling, K., Macdonald-Wallis, C., Sattar, N., Brion, M.J., Benfield, L., Ness, A., Deanfield, J., Hingorani, A., Nelson, S.M., Smith, G.D. \& Lawlor, D.A. 2010. Association of maternal weight gain in pregnancy with offspring obesity and metabolic and vascular traits in childhood. Circulation 121, 2557-2564.

Gabory, A., Attig, L. \& Junien, C. 2009. Sexual dimorphism in environmental epigenetic programming. Mol Cell Endocrinol 304, 8-18.

Geelhoed, J.J., Van Osch-Gevers, L., Verburg, B.O., Steegers, E.A., Hofman, A., Helbing, W., Witteman, J.C. \& Jaddoe, V.W. 2008. Maternal anthropometrics in pregnancy are associated with left ventricular mass in infancy. The generation R study. Pediatr Res 63, 62-66.

Gilbert, J.S., Lang, A.L., Grant, A.R. \& Nijland, M.J. 2005. Maternal nutrient restriction in sheep: hypertension and decreased nephron number in offspring at 9 months of age. J Physiol 565, 137-147.

Gregorio, B.M., Souza-Mello, V., Carvalho, J.J., Mandarimde-Lacerda, C.A. \& Aguila, M.B. 2010. Maternal high-fat intake predisposes nonalcoholic fatty liver disease in C57BL/ 6 offspring. Am J Obstet Gynecol 203, 495.e1-495.e8.

Hall, A.P., Elcombe, C.R., Foster, J.R., Harada, T., Kaufmann, W., Knippel, A., Kuttler, K., Malarkey, D.E., Maronpot, R.R., Nishikawa, A., Nolte, T., Schulte, A., Strauss, V. \& York, M.J. 2012. Liver hypertrophy: a review of adaptive (adverse and non-adverse) changes-conclusions from the 3rd International ESTP Expert Workshop. Toxicol Pathol 40, 971-994.

Han, H., Hansen, T.R., Berg, B., Hess, B.W. \& Ford, S.P. 2008. Maternal undernutrition induces differential cardiac gene expression in pulmonary hypertensive steers at high elevation. Am J Physiol Heart Circ Physiol 295, H382-H389. 
Heerwagen, M.J., Miller, M.R., Barbour, L.A. \& Friedman, J.E. 2010. Maternal obesity and fetal metabolic programming: a fertile epigenetic soil. Am J Physiol Regul Integr Comp Physiol 299, R711-22.

Huxley, R.R., Shiell, A.W. \& Law, C.M. 2000. The role of size at birth and postnatal catch-up growth in determining systolic blood pressure: a systematic review of the literature. J Hypertens 18, 815-831.

Huxley, R., Neil, A. \& Collins, R. 2002. Unravelling the fetal origins hypothesis: is there really an inverse association between birthweight and subsequent blood pressure? Lancet 360, 659-665.

Hyatt, M.A., Gardner, D.S., Sebert, S., Wilson, V., Davidson, N., Nigmatullina, Y., Chan, L.L., Budge, H. \& Symonds, M.E. 2011. Suboptimal maternal nutrition, during early fetal liver development, promotes lipid accumulation in the liver of obese offspring. Reproduction 141, 119-126.

Jimenez-Chillaron, J.C., Diaz, R., Martinez, D., Pentinat, T., Ramon-Krauel, M., Ribo, S. \& Plosch, T. 2012. The role of nutrition on epigenetic modifications and their implications on health. Biochimie 94, 2242-2263.

Khan, I.Y., Taylor, P.D., Dekou, V., Seed, P.T., Lakasing, L., Graham, D., Dominiczak, A.F., Hanson, M.A. \& Poston, L. 2003. Gender-linked hypertension in offspring of lardfed pregnant rats. Hypertension 41, 168-175.

Khan, I., Dekou, V., Hanson, M., Poston, L. \& Taylor, P. 2004. Predictive adaptive responses to maternal high-fat diet prevent endothelial dysfunction but not hypertension in adult rat offspring. Circulation 110, 1097-1102.

Khan, I.Y., Dekou, V., Douglas, G., Jensen, R., Hanson, M.A., Poston, L. \& Taylor, P.D. 2005. A high-fat diet during rat pregnancy or suckling induces cardiovascular dysfunction in adult offspring. Am J Physiol Regul Integr Comp Physiol 288, R127-R133.

Krasnow, S.M., Nguyen, M.L. \& Marks, D.L. 2011. Increased maternal fat consumption during pregnancy alters body composition in neonatal mice. Am J Physiol Endocrinol Metab 301, E1243-E1253.

Laitinen, J., Jaaskelainen, A., Hartikainen, A.L., Sovio, U., Vaarasmaki, M., Pouta, A., Kaakinen, M. \& Jarvelin, M.R. 2012. Maternal weight gain during the first half of pregnancy and offspring obesity at 16 years: a prospective cohort study. BJOG 119, 716-723.

Langley-Evans, S.C., Welham, S.J., Sherman, R.C. \& Jackson, A.A. 1996. Weanling rats exposed to maternal low-protein diets during discrete periods of gestation exhibit differing severity of hypertension. Clin Sci (Lond) 91, 607-615.

Latini, G., De Mitri, B., Del Vecchio, A., Chitano, G., De Felice, C. \& Zetterstrom, R. 2004. Foetal growth of kidneys, liver and spleen in intrauterine growth restriction: "programming" causing "metabolic syndrome" in adult age. Acta Paediatr 93, 1635-1639.

Lillycrop, K.A., Phillips, E.S., Jackson, A.A., Hanson, M.A. \& Burdge, G.C. 2005. Dietary protein restriction of pregnant rats induces and folic acid supplementation prevents epigenetic modification of hepatic gene expression in the offspring. J Nutr 135, 1382-1386.

Lillycrop, K.A., Phillips, E.S., Torrens, C., Hanson, M.A., Jackson, A.A. \& Burdge, G.C. 2008. Feeding pregnant rats a protein-restricted diet persistently alters the methylation of specific cytosines in the hepatic PPAR alpha promoter of the offspring. Br J Nutr 100, 278-282.

Lucas, A. 1998. Programming by early nutrition: an experimental approach. J Nutr 128, 401S-406S.

McCurdy, C.E., Bishop, J.M., Williams, S.M., Grayson, B.E., Smith, M.S., Friedman, J.E. \& Grove, K.L. 2009. Maternal high-fat diet triggers lipotoxicity in the fetal livers of nonhuman primates. J Clin Invest 119, 323-335.

McGavock, J.M., Victor, R.G., Unger, R.H., Szczepaniak, L.S. \& American College of Physicians and the American Physiological Society. 2006. Adiposity of the heart, revisited. Ann Intern Med 144, 517-524.

McMillen, I.C. \& Robinson, J.S. 2005. Developmental origins of the metabolic syndrome: prediction, plasticity, and programming. Physiol Rev 85, 571-633.

McMullen, S. \& Langley-Evans, S.C. 2005. Maternal lowprotein diet in rat pregnancy programs blood pressure through sex-specific mechanisms. Am J Physiol Regul Integr Comp Physiol 288, R85-R90.

Mouralidarane, A., Soeda, J., Visconti-Pugmire, C., Samuelsson, A.M., Pombo, J., Maragkoudaki, X., Butt, A., Saraswati, R., Novelli, M., Fusai, G., Poston, L., Taylor, P.D. \& Oben, J.A. 2013. Maternal obesity programs offspring non-alcoholic fatty liver disease via innate immune dysfunction in mice. Hepatology 58, 128-138.

Nohr, E.A., Vaeth, M., Baker, J.L., Sorensen, T.I., Olsen, J. \& Rasmussen, K.M. 2008. Combined associations of prepregnancy body mass index and gestational weight gain with the outcome of pregnancy. Am J Clin Nutr 87, 17501759.

Oben, J.A., Mouralidarane, A., Samuelsson, A.M., Matthews, P.J., Morgan, M.L., McKee, C., Soeda, J., Fernandez-Twinn, D.S., Martin-Gronert, M.S., Ozanne, S.E., Sigala, B., Novelli, M., Poston, L. \& Taylor, P.D. 2010. Maternal obesity during pregnancy and lactation programs the development of offspring non-alcoholic fatty liver disease in mice. J Hepatol 52, 913-920.

Oral, H., Dorn, G.W. II \& Mann, D.L. 1997. Sphingosine mediates the immediate negative inotropic effects of tumor necrosis factor-alpha in the adult mammalian cardiac myocyte. J Biol Chem 272, 4836-4842.

Ravelli, A.C., van der Meulen, J.H., Michels, R.P., Osmond, C., Barker, D.J., Hales, C.N. \& Bleker, O.P. 1998. Glucose tolerance in adults after prenatal exposure to famine. Lancet 351, 173-177.

Ravelli, A.C., van Der Meulen, J.H., Osmond, C., Barker, D.J. \& Bleker, O.P. 1999. Obesity at the age of $50 \mathrm{y}$ in men and women exposed to famine prenatally. Am J Clin Nutr 70, 811-816.

Roseboom, T.J., van der Meulen, J.H., Ravelli, A.C., van Montfrans, G.A., Osmond, C., Barker, D.J. \& Bleker, O.P. 1999. Blood pressure in adults after prenatal exposure to famine. J Hypertens 17, 325-330.

Samuelsson, A.M., Matthews, P.A., Argenton, M., Christie, M.R., McConnell, J.M., Jansen, E.H., Piersma, A.H., Ozanne, S.E., Twinn, D.F., Remacle, C., Rowlerson, A., Poston, L. \& Taylor, P.D. 2008. Diet-induced obesity in female mice leads to offspring hyperphagia, adiposity, hypertension, and 
insulin resistance: a novel murine model of developmental programming. Hypertension 51, 383-392.

Samuelsson, A.M., Matthews, P.A., Jansen, E., Taylor, P.D. $\&$ Poston, L. 2013. Sucrose feeding in mouse pregnancy leads to hypertension, and sex-linked obesity and insulin resistance in female offspring. Front Physiol 4, 14.

Savage, D.B. \& Semple, R.K. 2010. Recent insights into fatty liver, metabolic dyslipidaemia and their links to insulin resistance. Curr Opin Lipidol 21, 329-336.

Shankar, K., Kang, P., Harrell, A., Zhong, Y., Marecki, J.C., Ronis, M.J. \& Badger, T.M. 2010. Maternal overweight programs insulin and adiponectin signaling in the offspring. Endocrinology 151, 2577-2589.

Slater-Jefferies, J.L., Lillycrop, K.A., Townsend, P.A., Torrens, C., Hoile, S.P., Hanson, M.A. \& Burdge, G.C. 2011. Feeding a protein-restricted diet during pregnancy induces altered epigenetic regulation of peroxisomal proliferatoractivated receptor-alpha in the heart of the offspring. $J$ Dev Orig Health Dis 2, 250-255.

Sookoian, S., Rosselli, M.S., Gemma, C., Burgueno, A.L., Fernandez Gianotti, T., Castano, G.O. \& Pirola, C.J. 2010. Epigenetic regulation of insulin resistance in nonalcoholic fatty liver disease: impact of liver methylation of the peroxisome proliferator-activated receptor gamma coactivator 1alpha promoter. Hepatology 52, 1992-2000.

van Straten, E.M., Bloks, V.W., Huijkman, N.C., Baller, J.F., van Meer, H., Lutjohann, D., Kuipers, F. \& Plosch, T. 2010. The liver X-receptor gene promoter is hypermethylated in a mouse model of prenatal protein restriction. Am J Physiol Regul Integr Comp Physiol 298, R275R282.

Turdi, S., Ge, W., Hu, N., Bradley, K.M., Wang, X. \& Ren, J. 2013. Interaction between maternal and postnatal high fat diet leads to a greater risk of myocardial dysfunction in offspring via enhanced lipotoxicity, IRS-1 serine phosphorylation and mitochondrial defects. J Mol Cell Cardiol 55, 117-129.

Unterberger, A., Szyf, M., Nathanielsz, P.W. \& Cox, L.A. 2009. Organ and gestational age effects of maternal nutrient restriction on global methylation in fetal baboons. $J$ Med Primatol 38, 219-227.

Vaiman, D., Gascoin-Lachambre, G., Boubred, F., Mondon, F., Feuerstein, J.M., Ligi, I., Grandvuillemin, I., Barbaux, S., Ghigo, E., Achard, V., Simeoni, U. \& Buffat, C. 2011. The intensity of IUGR-induced transcriptome deregulations is inversely correlated with the onset of organ function in a rat model. PLOS ONE 6, e21222.

Vickers, M.H. 2007. Developmental programming and adult obesity: the role of leptin. Curr Opin Endocrinol Diabetes Obes 14, 17-22.

Wang, J., Ma, H., Tong, C., Zhang, H., Lawlis, G.B., Li, Y., Zang, M., Ren, J., Nijland, M.J., Ford, S.P., Nathanielsz, P.W. \& Li, J. 2010. Overnutrition and maternal obesity in sheep pregnancy alter the JNK-IRS-1 signaling cascades and cardiac function in the fetal heart. FASEB J 24, 2066 2076.

Yang, K.F., Cai, W., Xu, J.L. \& Shi, W. 2012. Maternal high-fat diet programs Wnt genes through histone modification in the liver of neonatal rats. J Mol Endocrinol 49, 107-114.

Zhang, J., Wang, C., Terroni, P.L., Cagampang, F.R., Hanson, M. \& Byrne, C.D. 2005. High-unsaturated-fat, highprotein, and low-carbohydrate diet during pregnancy and lactation modulates hepatic lipid metabolism in female adult offspring. Am J Physiol Regul Integr Comp Physiol 288, R112-R118. 